\title{
DNA microarray analysis in endometriosis for development of more effective targeted therapies
}

\author{
Sachiko Matsuzaki ${ }^{1,2}$
}

${ }^{1}$ Centre Hospitalier Universitaire de Clermont-Ferrand, Chirurgie Gynecologique, 1, Place Lucie Aubrac, 63003 ClermontFerrand Cedex 1, France, ${ }^{2}$ Universite d'Auvergne Clermont I, Centre d'Endoscopie et des Nouvelles Techniques Interventionnelles (CENTI), 2ETG Bâtiment 3C, 28, Place Henri Dunan, 63000 Clermont-Ferrand

\section{TABLE OF CONTENTS}

\author{
1. Abstract \\ 2. Introduction \\ 3. Gene expression \\ 3.1. $m R N A$ expression \\ 3.1.1. Immune system \\ 3.1.2. Angiogenesis \\ 3.1.3. Endometrial.peritoneal interaction \\ 3.1.4. Ovarian endometriosis vs endometriosis.dependent ovarian cancer \\ 3.1.5. Blood markers for non.invasive diagnostic tests \\ 3.1.6. Endometriotic cells in vitro \\ 4. Array $C G H$ \\ 3.2. MicroRNA expression \\ 5. Chromatin immunoprecipitation (ChIP) with hybridization of microarrays (ChIP.on.chip) \\ 6. Single nucleotide polymorphisms (SNPS) array7. Summary and Perspective \\ 8. Acknowledgements \\ 9. References
}

\section{ABSTRACT}

Microarray technology has become a widely used tool for analyzing the expression of tens of thousands of genes simultaneously on high-density microarrays in a single experiment, together with the availability of the complete nucleotide sequence of the human genome. DNA microarray technologies are powerful tools in the laboratory setting for scientific research, hypothesis generation, and the production of leads for subsequent validation through more sophisticated technologies. Since 2002, and particularly in the past few years, the utility of various DNA microarray technologies in endometriosis has rapidly and tremendously evolved; DNA microarray studies provide extremely important information that enable a better understanding of pathophysiology and disease etiology. This is a review of the literature focused on new findings of endometriosis pathophysiology obtained using various microarray technologies: gene expression profiling, microarray-based comparative genomic hybridization (CGH) (array CGH) single nucleotide polymorphism (SNP) arrays, the combination of chromatin immunoprecipitation (ChIP) with hybridization of microarrays (ChIP-on-chip). The present review discusses the results of a decade of DNA microarray technology experience, with emphasis on the pathophysiology of endometriosis in the context of clinical studies.

\section{INTRODUCTION}

Microarray technology has become a widely used tool for analyzing the expression of tens of thousands of genes simultaneously on high-density microarrays in a single experiment, together with the availability of the complete nucleotide sequence of the human genome. To date, use of DNA microarrays has primarily focused on evaluation of the transcriptome. However, advances in microarray technology have opened a wide range of new applications, such as microarray-based comparative genomic hybridization (CGH) (array CGH) for genome-wide detection of chromosomal deletions and amplifications, and single nucleotide polymorphism (SNP) arrays, which make it possible to conduct large-scale linkage analyses, association studies, and copy number studies. Furthermore, the combination of chromatin immunoprecipitation (ChIP) with hybridization of microarrays (ChIP-on-chip) is a powerful method for analyzing the methylation status of cytosine-phosphate-guanine (CpG) islands in promoter regions. Endometriosis is a polygenetically inherited disease with a complex multifactorial etiology (1). Thus, all of these DNA microarray technologies could potentially be powerful tools for elucidation of the molecular mechanisms underlying endometriosis pathophysiology.

This is a review of the literature focused on new findings of endometriosis pathophysiology obtained using the above-mentioned microarray technologies. Several 
studies have also investigated differential gene expression and DNA copy number alterations on eutopic endometrium from women with endometriosis using DNA microarray technologies (2-7). These studies clearly demonstrated that the endometrium of women with endometriosis fundamentally differs from that of women without endometriosis (2-7). The present review is limited to findings from endometriosis, and not eutopic endometrium of women with endometriosis, due to space restrictions.

The first global gene expression analysis of endometriosis by DNA microarray was published in Fertility Sterility in 2002 by Eyster et al (8) (Table 1). Now, almost 10 years later, the present review discusses the results of a decade of DNA microarray technology experience, with emphasis on the pathophysiology of endometriosis in the context of clinical studies. The aim of all studies described was to identify endometriosis markers that can be used for non-invasive diagnosis and for development of strategies for prevention and more effective targeted therapies, and to gain a better understanding of endometriosis pathophysiology and etiology.

A systematic MEDLINE search was performed using the key words "endometriosis," "DNA microarray," "gene expression," "microRNA," "epigenetics," "DNA copy number," and "genome-wide association study," through August 2010 and restricted to papers published in English.

\section{GENE EXPRESSION}

\section{1. mRNA expression}

Prior to the establishment of true cDNA microarray, so-called "macroarrays," in which cDNA library clones were spotted on large membrane sheets to hybridize radiolabeled cDNA pools generated from total or purified mRNA, were developed (22). Subsequently, new carrier materials (i.e., glass slides) and fluorescence-based signal detection were established (23). These arrays are traditionally used with a two-color detection system; i.e., mRNA from a sample and a control are labeled with fluorescent $\mathrm{Cy} 3$ and $\mathrm{Cy} 5$ dyes and hybridized to the same array. Therefore, these two-color arrays produce a ratio indicating the differential expression between the sample and the control. Technologies have rapidly evolved (24-27), and new developments in automation, robotic spotting, and bioinformatics subsequently led to rapid growth in microarray usage. The current version of Affymetrix GeneChips (Human Genome U133 Plus 2.0) provides comprehensive coverage of the transcribed human genome on a single array representing 47,000 transcripts and variants, including 38,500 well-characterized human genes, while that of GE Healthcare (CodeLink Whole Human Genome Bioarrays) provides 57,000 transcripts and ESTs, including $\sim 45,000$ well-characterized human genes. Furthermore, in contrast to two-color arrays, these technologies use a standardized biotin-labeling protocol and produce an intensity signal that enables absolute quantification (Table 1) (8-21).

\subsubsection{Immune system}

The immune system is believed to be involved in the pathogenesis of endometriosis (1). Two DNA microarray studies, which used the most recent microarray systems, demonstrated that genes associated with immune responses represent the most functional class $(15,17)$ (Table 1). In one study (17), 10 ovarian endometriosis samples and 10 matched control endometrium samples from the same patients were analyzed using the Affymetrix U133 plus 2.0 genome-wide gene array. In addition, 10 uterine fibroid samples and 10 adenomyosis samples, which are also estrogen-dependent gynecological benign diseases, were also included in the cDNA microarray analysis (17). This study demonstrated that genes associated with immune responses represent the most functional class in ovarian endometriosis (17). In contrast, no immune response-associated pathways were detected in the uterine fibroid of adenomyosis samples (17). Of the immune response genes identified, the study authors focused on B lymphocyte stimulator (BLyS, also know as BAFF and tumor necrosis factor ligand superfamily member 13b), a cytokine that is required for normal B cell development (28). Expression levels of BLyS mRNA, as well as BCMA (one of the three receptors for BLyS), were highly up-regulated in ovarian endometriosis (17). In addition, BLyS protein was elevated in the sera of 31 endometriosis patients compared to 21 healthy controls (17). Patients with uterine fibroids or adenomyosis did not have elevated BLyS serum compared to controls (17). An excess of BLyS has been shown to lead to the development of autoimmune disorders in animal models (29-31). In addition, elevated serum BLyS levels have been reported to be elevated in patients with systemic lupus erythematosus (SLE), rheumatoid arthritis (RA), and other systemic immune-based rheumatic disease $(32,33)$, and a relationship exists between circulating BLyS levels and SLE disease activity (34). An epidemiological study reported an increased prevalence of autoimmune diseases in women with endometriosis compared to the general US female population (35). For example, women with endometriosis had higher rates of RA (1.8 versus $1.2 \%, \mathrm{P}=$ $0.001)$ and SLE ( 0.8 versus $0.04 \%, \mathrm{P}<0.0001)$ (35). Now, promising results have been released from two phase III clinical trials (BLISS-52 and BLISS-76) evaluating belimumab, an inhibitor of BLyS, for the treatment of SLE, in which 865 and 819 patients were treated, respectively (36). Another study using a whole-genome DNA microarray containing 53,000 human transcripts in 11 endometriotic samples (6 ovarian endometriosis, 5 peritoneal endometriosis) also demonstrated that the largest group of differentially expressed genes included the family of genes associated with inflammation and immune response (15). Very importantly, BLyS expression was significantly higher in endometriosis samples compared to eutopic endometrium (15). Thus, immune responses might play a key role in endometriosis pathophysiology, and BLyS might be a potential therapeutic target in endometriosis.

\subsubsection{Angiogenesis}

Angiogenesis plays a key role in endometriotic lesion formation and development (1). A large amount of data has demonstrated that endometriosis is an angiogenesis-dependent disease (37). However, a wholegenome DNA microarray containing 53,000 human 
DNA microarray analysis in endometriosis

Table 1. Published mRNA expression studies on endometriosis using DNA microarray technology

\begin{tabular}{|c|c|c|c|c|c|c|c|c|}
\hline Technology & $\begin{array}{l}\text { No of } \\
\text { genes/EST } \\
\text { s }\end{array}$ & $\begin{array}{l}\text { Types of } \\
\text { endometriosis }\end{array}$ & Materials used & $\begin{array}{l}\text { Microarray } \\
\text { data }\end{array}$ & $\begin{array}{l}\text { Criteria for } \\
\text { identification } \\
\text { of differentially } \\
\text { expressed genes } \\
\end{array}$ & $\begin{array}{l}\text { No of differentially } \\
\text { expressed genes }\end{array}$ & key findings & Reference \\
\hline $\begin{array}{l}\text { cDNA on nylon } \\
\text { membrane }\end{array}$ & 4133 & $\overline{\mathrm{OE}}$ & $\begin{array}{lr}\text { Matched } & \text { eutopic } \\
(\mathrm{n}=3) \text { vs ectopic }(\mathrm{n}=3) \\
\text { endometrium }\end{array}$ & N.A. & $?$ & $\begin{array}{l}8 \text { genes (all up- } \\
\text { regulated vs eutopic } \\
\text { endometrium) }\end{array}$ & $\begin{array}{l}\text { Differentially expressed genes: } \\
\text { beta-actin, alpha-2 actin, } \\
\text { vimentin, } 40 \mathrm{~S} \text { ribosomal protein } \\
\text { S23, Ig-lambda light chain, Ig } \\
\text { germline } \mathrm{H} \text { chain G-E-A region } \\
\text { gamma-2 constant region gene, } \\
\text { major histocompatibility } \\
\text { complex class 1,C, and } \\
\text { complement component } 1 \mathrm{~S} \\
\text { subcomponent. }\end{array}$ & 8 \\
\hline $\begin{array}{l}\text { cDNA on nylon } \\
\text { membrane }\end{array}$ & 597 & $\begin{array}{l}\mathrm{OE} \\
\text { Controls : } \\
\text { endometrium } \\
\text { from patients } \\
\text { with uterine } \\
\text { fibroma } \\
\end{array}$ & $\begin{array}{lr}\text { Endometriotic stromal } \\
\text { cells }(\mathrm{n}=8) & \mathrm{vs} \\
\text { endometrial } & \text { stromal } \\
\text { cells }(\mathrm{n}=4) & \text { treated } \\
\text { with IL-1 beta } & \end{array}$ & N.A. & $\mathrm{P}<.05$ & $?$ & $\begin{array}{l}\text { Down-regulation of Tob-1 in } \\
\text { endometriotic stromal cells }\end{array}$ & 9 \\
\hline $\begin{array}{l}\text { cDNA on glass } \\
\text { slide }\end{array}$ & 23040 & $\mathrm{OE}$ & 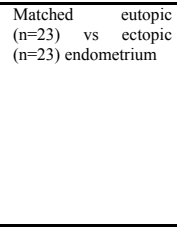 & N.A. & Ratio $<0.5$ or $>2.0$ & 1413 genes & $\begin{array}{l}\text { 1. Up regulation of } 15 \text { genes } \\
\text { throughout the menstrual cycle.: } \\
\text { e.g. } \\
\text { HLA antigens, complement } \\
\text { factors, ribosomal proteins, } \\
\text { TGFBI } \\
\text { 2. Down-regulation of } 337 \\
\text { genes throughout the menstrual } \\
\text { cycle: e.g. TP53, genes related } \\
\text { to apoptosis such as GADD34, } \\
\text { GADD45A, GADD45B } \\
\end{array}$ & 10 \\
\hline $\begin{array}{l}\text { cDNA on nylon } \\
\text { membrane }\end{array}$ & 1176 & $\begin{array}{l}\mathrm{DIE} \\
\end{array}$ & 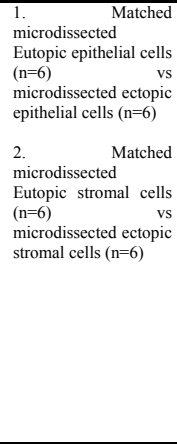 & N.A. & $\begin{array}{l}\text { Fold change }>2 \\
\text { in at least } \\
\text { two of three } \\
\text { samples }\end{array}$ & $?$ & $\begin{array}{l}\text { 1. Involvment of the } \\
\text { RAS/RAF/MAPK signaling } \\
\text { pathway through PDGFRA in } \\
\text { endometriosis pathophysiology. } \\
\text { 2. Down-regulation of two } \\
\text { potential negative regulators of } \\
\text { aromatase expression, chicken } \\
\text { ovalbumin upstream promoter } \\
\text { transcription factor } 2 \text { (COUP- } \\
\text { TF2) and prostaglandin E2 } \\
\text { receptor subtype EP3 } \\
\text { (PGE2EP3) in endometriosis } \\
\text { epithelial cells. } \\
\text { 3. Uup-regulation of tyrosine } \\
\text { kinase receptor B (TRkB) in } \\
\text { endometriosis epithelial cells } \\
\text { and serotonin transporter } \\
\text { (5HTT) and mu upioid receptor } \\
\text { (MOR) in endometriosis } \\
\text { stromal cells, which might be } \\
\text { involved in endometriosis } \\
\text { related pain }\end{array}$ & 11 \\
\hline $\begin{array}{l}\text { CDNA on glass } \\
\text { slide }\end{array}$ & 9600 & $\begin{array}{l}\mathrm{OE}(\mathrm{n}=7) \\
\mathrm{PE}(\mathrm{n}=5)\end{array}$ & $\begin{array}{l}\text { Matched } \\
\text { microdissected } \\
\text { Eutopic epithelial cells } \\
(\mathrm{n}=12) \quad \mathrm{vs} \\
\text { microdissected ectopic } \\
\text { epithelial cells }(\mathrm{n}=12)\end{array}$ & N.A. & $\begin{array}{l}\text { Structural } \\
\text { modeling } \\
\text { taking phase } \\
\text { and location } \\
\text { into account }\end{array}$ & 904 genes/ESTs & $\begin{array}{l}\text { 1. Identification of a total of } 79 \\
\text { pathways with known functions } \\
\text { (e.g. oxidative stress, focal } \\
\text { adhesion, Wnt signaling, and } \\
\text { MAPK signalling) } \\
\text { 2. Expression patterns of } \\
\text { differentially expressed } \\
\text { genes/ESTs correctly classified } \\
\text { the } 12 \text { patients into ovarian } \\
\text { and peritoneal endometriosis. }\end{array}$ & 12 \\
\hline $\begin{array}{l}\text { cDNA on glass } \\
\text { slide }\end{array}$ & 25097 & $?$ & $\begin{array}{lr}\text { Peripheral } & \text { blood } \\
\text { lymphocytes } & \text { from } \\
\text { patients } & \text { with } \\
\text { endometriosis } & (\mathrm{n}=6) \\
\text { vs Patients } & \text { without } \\
\text { endometriosis }(\mathrm{n}=4) & \\
\end{array}$ & N.A. & $\begin{array}{lr}\text { Weight } & >4.0 \\
\text { Groupwise } & \text { averaged } \\
\text { fold change [mean } & \\
\text { ratio difference } & \text { differ } \\
\text { between the two } \\
\text { groups] of }>2.0\end{array}$ & $?$ & $\begin{array}{l}\text { Up-regulation of interleukin-2 } \\
\text { receptor gamma (IL-2Rgamma) } \\
\text { and down-regulation of lysyl } \\
\text { oxidase-like 1 (LOXL1) }\end{array}$ & 13 \\
\hline Oligonucleotide & 18400 & DIE & $\begin{array}{l}\text { Pooled microdissected } \\
\text { vessels isolated from } \\
\text { the stroma }(\mathrm{n}=1) \text {, from } \\
\text { the fibromuscular } \\
\text { tissue ( } \mathrm{n}=4 \text { ) of deep } \\
\text { infilltrating } \\
\text { endometriosis, pooled } \\
\text { microdissected vessles } \\
\text { isolated from controls } \\
\text { tissues (endometrium: } \\
\mathrm{n}=4 \text {, myometrium: } \\
\mathrm{n}=1 \text { ) vs whole tissue } \\
\text { control pool (vagina: } \\
\mathrm{n}=1 \text {, endometrium: } \\
\mathrm{n}=3 \text {, myometrium: } \\
\mathrm{n}=1)\end{array}$ & $\begin{array}{l}\text { Array Express } \\
\text { data base } \\
\text { (www.ebi.ac.u } \\
\text { k/arrayexpress) } \\
\text { Accession } \\
\text { number: } \\
\text { E-MEXP-1251 }\end{array}$ & $\mathrm{P}<.05$ & $\begin{array}{l}\text { 1. Up-regulation of } \\
734 \text { transcripts in } \\
\text { vessels from } \\
\text { fibromuscular tissue } \\
\text { of endometriotic } \\
\text { nodules vs vessels } \\
\text { from control tissues. } \\
2 \text {. Up-regulation of } \\
923 \text { genes } \\
\text { in vessels from } \\
\text { stromal tissues of } \\
\text { endometriotic nodules } \\
\text { vs vessels from } \\
\text { control tissues. } \\
\text {. }\end{array}$ & $\begin{array}{l}\text { Strong overexpression for } \\
\text { several angiogenic } \\
\text { factors, extracellular matrix } \\
\text { components, surface } \\
\text { glycoproteins, mediators of } \\
\text { integrin signaling, receptors, } \\
\text { mediators of immune response } \\
\text { and transcription factors. }\end{array}$ & $\begin{array}{l}14 \\
2007\end{array}$ \\
\hline oligonucleotide & 53000 & $\begin{array}{l}\mathrm{OE}(\mathrm{n}=6) \\
\mathrm{PE}(\mathrm{n}=5)\end{array}$ & 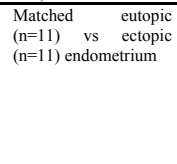 & $\begin{array}{l}\text { Gene } \\
\text { Expression } \\
\text { Omnibus } \\
\text { (www.ncbi.nl } \\
\text { m.nih.gov/geo) } \\
\text { Accession } \\
\text { number: } \\
\text { GSE5108 }\end{array}$ & $\begin{array}{l}\mathrm{P}<.05 \\
\text { Fold change }>2\end{array}$ & 717 genes & $\begin{array}{l}\text { 1.Identification of differentially } \\
\text { expressed } \\
\text { genes involved in signal } \\
\text { transduction, } \\
\text { cell adhesion, extracellular } \\
\text { matrix, cytoskeletal } \\
\text { organization, peptidases, } \\
\text { catalytic, and defense immunity }\end{array}$ & 15 \\
\hline $\begin{array}{l}\text { cDNA on nylon } \\
\text { membrane }\end{array}$ & 1176 & $\mathrm{OE}$ & $\begin{array}{lr}\text { Pooled } & \text { ovarian } \\
\text { endometriosis from } 5 \\
\text { patients vs pooled } \\
\text { endometrium from } 5 \\
\text { patients } & \text { without } \\
\text { endometriosis } & \\
\end{array}$ & N.A. & Fold change $>2$ & 13 genes & $\begin{array}{l}\text { 1. Up regulation of } 9 \text { genes and } \\
\text { down regulation of } 4 \text { genes vs } \\
\text { endometriuml after repeating } \\
\text { the gene analysis three times. }\end{array}$ & 16 \\
\hline oligonucleotide & 47000 & $\mathrm{OE}$ & 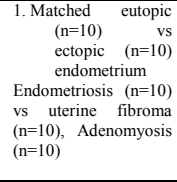 & $\begin{array}{l}\text { Gene } \\
\text { Expression } \\
\text { Omnibus } \\
\text { (www.ncbi.nl } \\
\text { m.nih.gov/geo) } \\
\text { Accession } \\
\text { number: } \\
\text { GSE7035 }\end{array}$ & 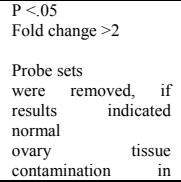 & $?$ & $\begin{array}{l}\text { Genes associated with immune } \\
\text { responses represent the most } \\
\text { significant functional class in } \\
\text { endometriosis, including } 53 \\
\text { genes with altered expression }\end{array}$ & 17 \\
\hline
\end{tabular}




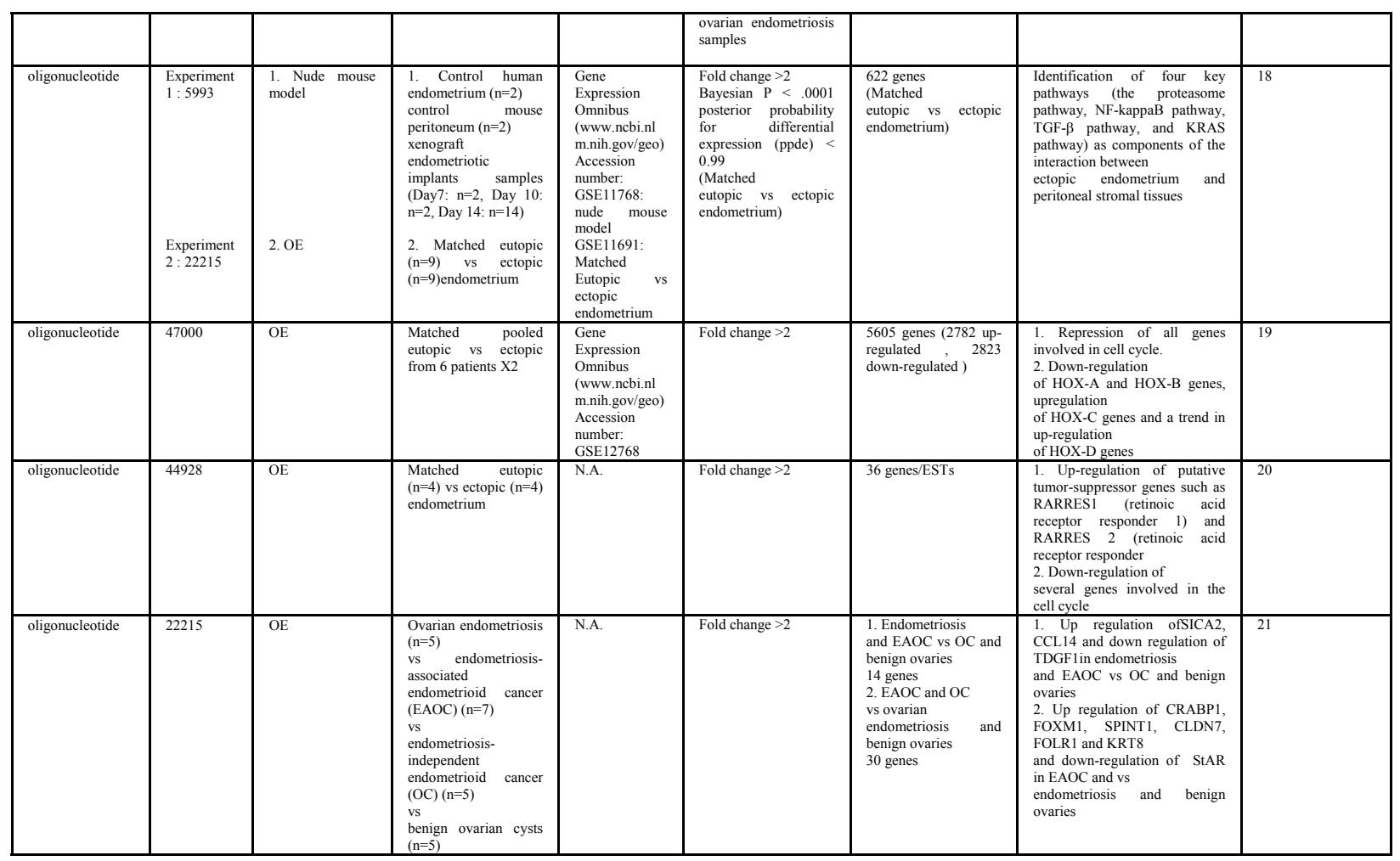

Note : ESTs (Expressed Sequence Tag); PE: Peritoneal endometriosis; OE: Ovarian endometriosis; DIE: Deep infiltrating endometriosis, N.A.: not available

transcripts identified only three conventional angiogenic factors: vascular endothelial growth factor, angiopoietinlike 1, and fibroblast growth factor 7 (15). As whole endometriotic tissues were used for expression analysis, low-expressing genes might not have been detected (15) (Table 1). Van Langendonckt et al. investigated gene expression profiling of the vasculature of fibromuscular and stromal tissue of endometriotic nodules of the rectovaginal septum to identify novel antigens for use as potential targets in the design of more specific diagnostic and treatment tools (14). For this purpose, laser capture microdissection (LCM) was applied to obtain endothelial cells and pericytes from endometriotic and endometrial tissues, as well as myometrial tissues (14). The LCM technique not only increases the specificity of profiling isolated cell populations, thereby eliminating genes expressed by surrounding cells, but it also increases the sensitivity of the analysis, allowing the detection of low-expressing genes not detected in whole-tumor arrays (38). The Affymetrix HG-U133A_2.0 chip allows analysis of the expression levels of 18,400 transcripts and variants, including 14,500 well-characterized human genes (14). One of the genes identified as a potential vessel marker in deep infiltrating endometriosis, matrix Gla protein (MGP), is of particular interest (14). Expression of MGP has been reported in vascular endothelium in different species, suggesting that MGP plays a role in endothelial cell function (14). MGP has been demonstrated to be strongly expressed in vascular endothelial cells and in epithelial cells from endometriotic tissues at the protein level (14). Importantly, MGP is expressed at a barely detectable level in normal endometrium (14). Thus, MGP might be one of the most promising markers for targeting ectopic endometrial vessels. Interestingly, overexpression of extracellular matrix genes has been consistently observed in previous studies of tumor endothelial markers in which endothelial cells were isolated by various methods, such as immunomagnetic beads and LCM (39-41). These findings suggest that changes in the extracellular matrix are fundamental to alterations in the tumor endothelium.

\subsubsection{Endometrial-peritoneal interaction}

To date, the majority of endometriosis gene expression profiling studies have evaluated genes that are differentially expressed between eutopic and ectopic endometrium (Table 1). However, it is necessary to also understand the molecular interactions between ectopic endometrial tissues and their attachment sites. Growing evidence suggests that endometriosis is a peritoneal disease (42). Hull et al. investigated these molecular interactions in a xenograft mouse model (18) (Table1). Endometriosis-like lesions were collected from nude mice on days 7, 10, and 14 after human endometrial tissue implantation (18). These investigators applied novel microarray analysis methods to distinguish RNA transcripts derived from human (endometrium) and mouse cells (peritoneum) using a MGU-74Av2 (mouse) and HU-95Av2 (human) Affymetrix GeneChip (18). In addition, microarray analysis was performed in paired peritoneal endometriosis and eutopic endometrium using U133A Affymetrix cDNA arrays (18). The study authors identified four key pathways: the proteasome pathway, NF-kappaB pathway, TGF- $\beta$ pathway, 
and KRAS pathway, demonstrating communication between host peritoneal cells and ectopic endometrial cells (18). They concluded that disruption of the dialogue between peritoneum and ectopic endometrium is likely to inhibit the cellular interactions required for endometriotic lesion development (18). Delineating the interactions between endometrial tissue and its ectopic environment may be the first step in the development of novel pharmacological therapies for this disabling condition. Further studies that investigate endometrial-peritoneal interaction in established endometriotic lesions might provide insights on this new, important therapeutic direction.

A study in a mouse model of surgically-induced endometriosis focused on gene expression profiling of the peritoneal side at 24, 48, and 96 hours after autotransplantation (43). The Mouse FANTOM Array ver. 1 consisting of 13,728 gene probes and samples labeled with fluorescent $\mathrm{Cy} 3$ and $\mathrm{Cy} 5$ dyes were used. The study authors identified up-regulation of genes associated with inflammatory response, adhesion molecules, and extracellular matrix, followed by inflammation and cytokine expression, activation of antibody-producing cells and dendritic cells, and local immunosuppression. In addition, the microarray analysis demonstrated that downregulation of genes associated with lymphokines, chemokine receptors, phagocytes, and monocytes is induced in these lesions (43). The authors concluded that this observation may explain the localized immunotolerance against ectopic endometrial cells in the peritoneal cavity (43). Interestingly, many similarities exist between findings obtained in a xenograft mouse model and a surgically-induced mouse model by autotransplantation of uterine fragments, i.e., genes associated with inflammatory response, adhesion molecules, and extracellular matrix (18, 43). Two studies in a surgically-induced rodent model developed by autotransplantation of uterine fragments identified gene expression patterns consistent with human disease $(44,45)$. These findings also supported the results of previous studies indicating that rodent models of surgically-induced endometriosis can be used to study the pathophysiology and treatment of endometriosis. In addition to xenograft mouse models, autologous rodent models might also be useful for evaluation of new therapeutics designed to induce disruption of the dialogue between peritoneum and ectopic endometrium.

\subsubsection{Ovarian endometriosis vs endometriosis- dependent ovarian cancer}

Endometriosis is a benign disease. However, it is believed to be a precursor for ovarian cancer (46-49). In particular, clear-cell and endometrioid ovarian cancer have been reported to be associated with ovarian endometriosis (46-49). Interestingly, DNA microarray analysis has revealed a significant correlation between gene expression in the endometrial mucosa and in endometrioid and clearcell carcinomas (50). However, the mechanism of malignant transformation of ovarian endometriosis has not yet been elucidated. Banz et al. analyzed the molecular signature of endometriosis-associated endometrioid ovarian cancer, endometriosis-independent endometrioid ovarian cancer, ovarian endometriosis, and benign ovarian cysts using the Affymetrix HG U133A/MG U74Av2 array (21) (Table 1). The study results suggested that the regulation of the autoimmune system and of inflammatory cytokines may be very important in the etiology of ovarian endometriosis and endometriosis-associated endometrioid ovarian cancer. In addition, cell-cell interaction, cell differentiation, and cell proliferation may be important in the development of ovarian cancer in women with endometriosis. Cancer is characterized by uncontrolled cell growth, invasion, and sometimes metastasis. The results of Banz et al. suggested that a switch from controlled to uncontrolled cell proliferation might be a cause of endometriosis-associated endometrioid ovarian cancer. Borghese et al. demonstrated a systemic down-regulation of genes involved in the cell cycle in ovarian endometriosis, using the NimbleGen platform containing 47,633 transcripts (19) (Table 1). In addition, another group of investigators demonstrated the up-regulation of putative tumor-suppressor genes such as RARRES1 (retinoic acid receptor responder 1) and RARRES 2 (retinoic acid receptor responder 2) in ovarian endometriosis (20) (Table 1). Furthermore, several genes involved in the cell cycle were down-regulated (20) (Table 1). The most extensive study to date using a GE Healthcare platform containing 53,000 transcripts identified few genes involved in the cell cycle and in apoptosis-resistant pathways (15) (Table 1). However, an analysis using cDNA microarrays and LCM demonstrated that endometriotic epithelial cells of ovarian endometriosis and peritoneal endometriosis revealed high expression levels of genes responsible for cell proliferation and the cell cycle (12) (Table 1). In addition, the study authors also identified many cell cycle genes as being differentially expressed between endometriotic epithelial cells and eutopic endometrial epithelial cells, suggesting that the cell cycle was disturbed in the endometriotic cells (19) (Table 1). One potential explanation for these findings is that disturbed cell cycling in endometriotic epithelial cells might be protected by stromal cells or their microenvironment in vivo.

Direct interactions between epithelial and stromal cells and their microenvironments are required both for normal and pathological tissue development and growth $(51,52)$. There is growing evidence that the tumor microenvironment is indispensable for the neoplastic process (52). Additional studies designed to investigate how the disturbed cell cycle of endometriotic epithelial cells is tightly controlled might provide further insights on the molecular mechanisms of malignant transformation of ovarian endometriosis.

\subsubsection{Blood markers for non-invasive diagnostic tests}

Developing non-invasive diagnostic tests that accurately detect endometriosis is considered to be one of the main priorities in endometriosis research (53). Blood-borne (blood/serum/plasma) markers are favored by clinicians, because blood samples can be obtained and analyzed with relative ease. To date, only one study that investigated peripheral blood lymphocytes in patients with and without endometriosis using DNA microarrays to identify molecular markers for 
endometriosis has been published (13) (Table 1). The array had 15,097 cDNA clones, of which 14,185 were known genes, and samples were labeled with fluorescent $\mathrm{Cy} 3$ and Cy 5 dyes. Samples from 6 patients with endometriosis and 4 controls were used for microarray analysis, and a $\mathrm{qPCR}$ validation study was performed in 15 patients with endometriosis and 15 controls. These researchers identified up-regulation of interleukin-2 receptor gamma (IL-2Rgamma) and down-regulation of lysyl oxidase-like 1 (LOXL1) in patients with endometriosis (13). However, the study authors noted that factors that may affect lymphocyte gene expression patterns, such as menstrual cycle phase, concurrent infections, and current medications, were not analyzed due to the small number of patients. It would be interesting to investigate the impact of clinical variables such as menstrual cycle, severity of disease, and symptoms on these potential markers in a larger population. However, Somigliana et al. recently published an opinion paper on non-invasive tests for the diagnosis of endometriosis (54). These investigators emphasized that researchers should be aware that the identification of a non-invasive test for the diagnosis of endometriosis may be harmful if its use is not properly managed, and that a non-invasive test may be beneficial provided that it is not used as a screening test (54). They recommended that non-invasive tests for the diagnosis of endometriosis should be reserved for only two groups of women who may benefit from the diagnosis: those with unexplained subfertility and those with unexplained severe pelvic pain refractory to oral contraceptives and NSAIDs (54). This recommendation might be useful when considering the design of future studies aimed at identifying non-invasive endometriosis diagnostic markers.

\subsubsection{Endometriotic cells in vitro}

In vitro analysis of primary epithelial and stromal endometriotic cells is indispensable for endometriosis research. Recent studies have applied targeted arrays in endometriotic cells to investigate specific cell signaling pathways potentially involved in endometriosis pathophysiology in vitro $(55,56)$. The expression profile for marker genes of 21 different signaling pathways and the NF-kappaB pathway in response to the addition of TNF-alpha to endometriotic stromal cells was investigated using a cDNA array (55). TNF-alpha and its downstream target TAK-1 have been demonstrated to be key mediators of NF-kappaB and MAPK signaling in endometriosis. In addition, abnormal cell survival in ectopic sites is key to endometriosis pathophysiology (57). Studies demonstrated that susceptibility to drug-induced apoptosis in endometriotic stromal cells was attenuated compared to endometrial stromal cells (58). Watanabe et al. further investigated genes susceptible to staurosporine (SS)-induced apoptosis in endometriotic stromal cells using a targeted cDNA array containing 96 marker genes involved in the regulation and mediation of apoptosis (56). Survivin has been demonstrated to play a key anti-apoptotic role in endometriotic cells in vitro. Survivin is a member of the inhibitor of apoptosis (IAP) family and functions by inhibiting caspase (59). Interestingly, a study that investigated endometriotic stromal-epithelial cell communication demonstrated that the loss of the ability to regulate survival signaling in endometriotic stromal cells might result in increased survivin expression in endometriotic epithelial cells (60), To date, however, very few studies have investigated primary endometriotic epithelial cells in vitro. Further studies in both endometriotic epithelial cells and stromal cells as well as their interactions could provide further insight on endometriosis pathophysiology.

\subsection{MicroRNA expression}

Wren and Guo reanalyzed their own database of 904 differentially expressed genes between endometriosis and eutopic endometrium (12) to identify associations between genes, disease, phenotypes, chemical compounds, and pharmaceuticals based upon what has been reported in the published literature (61). These investigators determined that several genes listed as non-responders on the microarray were post-transcriptionally regulated. MicroRNAs (miRNAs) are post-transcriptional regulators that bind to complementary sequences in the 3' UTRs of target mRNAs, resulting in translation inhibition or mRNA cleavage, depending on the degree of complementarity between the miRNA and its target sequence $(62,63)$. Given that miRNAs can have multiple targets and that each protein-coding gene can be targeted by multiple miRNAs, it has been suggested that more than one-third of human genes could be regulated by miRNAs $(61,62)$. To date, three groups have investigated miRNA expression profiling in endometriosis using DNA microarray techniques (64-66) (Table 2). Details about miRNA in endometriosis are reviewed elsewhere (67). Of these, one study further identified predictive targets of differentially expressed miRNAs in endometriosis using their own mRNA microarray data acquired by U133A Affymetrix cDNA arrays (65). The study authors identified 14 up-regulated and 8 down-regulated miRNAs, using microarrays that consisted of 377 antisense miRNA oligonucleotideprobes (65). A total of 673 genes representing mRNAs expressed in peritoneal endometriosis are predicted targets of any of the 22 differentially expressed miRNAs (65). Among them, miR-1 and miR-29c were determined to be up-regulated in endometriosis (65). By functional analysis of predicted target genes based on the identified miRNAs, HADC4 and DNMT3A were found to be among the target genes of miR-1 and miR-29c, respectively (65). A later study using a $\mu$ Paraflo microfluidic chip containing 475 miRNA probes also identified up-regulation of miR-1 and miR-29c in ovarian endometriosis (66). These findings support the growing evidence that endometriosis is an epigenetic disease and suggested that miR-1 and miR-29c might play a role in epigenetic modifications in endometriosis. In addition, two studies identified down-regulation of miR20a in peritoneal and ovarian endometriosis. CCND1 and the E2F family of transcription factors were found to be among the target genes of miR-20a $(65,66)$. A study demonstrated a CCND1/miR-17/20 regulatory feedback loop through which cyclin D1 induces miR-17-5p/miR-20a (67). In turn, miR-17/20 limits the proliferative function of cyclin D1. These attenuating feedback loops provide 
Table 2. Published microRNA expression studies on endometriosis using microRNA microarray technology

\begin{tabular}{|c|c|c|c|c|c|c|c|}
\hline Platform & $\begin{array}{ll}\text { No. } & \text { of } \\
\text { microRNA }\end{array}$ & $\begin{array}{l}\text { Types } \\
\text { endometriosis }\end{array}$ & Materials used & $\begin{array}{l}\text { Criteria for } \\
\text { identification } \\
\text { of differentially } \\
\text { expressed } \\
\text { microRNAs }\end{array}$ & $\begin{array}{l}\text { No } \\
\text { differentially } \\
\text { expressed } \\
\text { microRNAs }\end{array}$ & Key findings & Reference \\
\hline $\begin{array}{l}\text { mirVana } \\
\text { miRNA } \\
\text { Bioarray }\end{array}$ & 377 & $?$ & $\begin{array}{l}\begin{array}{l}\text { 1. Matched } \\
\text { eutopic }(\mathrm{n}=4) \quad \mathrm{vs} \\
\text { ectopic }(\mathrm{n}=4) \\
\text { endometrium }\end{array} \\
\begin{array}{l}\text { 2. Endometriosis } \\
(\mathrm{n}=4)\end{array} \\
\begin{array}{l}\text { 3. Endometrium } \\
\text { from women } \\
\text { without } \\
\text { endometriosis } \\
(\mathrm{n}=4)\end{array}\end{array}$ & $\mathrm{P}<.05$ & 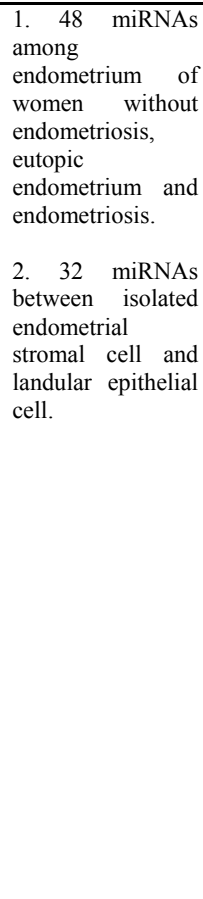 & $\begin{array}{l}\text { 1. Expression of } \\
\text { hsa-miR20a, hsa- } \\
\text { miR21, hsa- } \\
\text { miR26a, hsa- } \\
\text { miR18a, hsa- } \\
\text { miR206, } \\
\text { hsa-miR181a and } \\
\text { hsa-miR142-5p, } \\
\text { predicted to target } \\
\text { many genes, } \\
\text { including TGF- } \\
\text { bR2, ERa, ERb } \\
\text { and PR, was } \\
\text { altered in } \\
\text { endometriosis } \\
\text { compared with } \\
\text { eutopic } \\
\text { endometrium and } \\
\text { control } \\
\text { endometrium. } \\
\text { 2. } \\
\text { steroids influence } \\
\text { the } \\
\text { expression of hsa- } \\
\text { miR20a, hsa- } \\
\text { miR21 and hsa- } \\
\text { miR26a in } \\
\text { endometrial } \\
\text { stromal cell and } \\
\text { glandular } \\
\text { epithelial cell. }\end{array}$ & 59 \\
\hline $\begin{array}{l}\text { mirVana } \\
\text { miRNA } \\
\text { Bioarray }\end{array}$ & 287 & $\mathrm{PE}$ & $\begin{array}{l}\text { Matched eutopic } \\
(\mathrm{n}=4) \text { vs ectopic } \\
(\mathrm{n}=4) \\
\text { endometrium }\end{array}$ & $\begin{array}{l}\mathrm{P}<.05 \\
\text { Fold change } \geq 2\end{array}$ & 22 miRNAs & $\begin{array}{l}\text { 1. An in silico and } \\
\text { microarray } \\
\text { analysis (eutopic } \\
\text { vs ectopic } \\
\text { endometrium) } \\
\text { identified } 673 \\
\text { genes, including } \\
\text { c-Jun, CREB- } \\
\text { binding protein, } \\
\text { protein kinase B } \\
\text { (Akt), and cyclin } \\
\text { D1 (CCND1) } \\
\text { signalling, } \\
\text { as putative targets } \\
\text { of the } 22 \\
\text { miRNAs. }\end{array}$ & 60 \\
\hline $\begin{array}{l}\text { Paraflo }^{\mathbb{R}} \\
\text { Microfluidic } \\
\text { Biochip }\end{array}$ & 475 & $\mathrm{OE}$ & $\begin{array}{l}\text { Matched eutopic } \\
(\mathrm{n}=16) \text { vs ectopic } \\
(\mathrm{n}=16) \\
\text { endometrium }\end{array}$ & $\begin{array}{l}\mathrm{P}<.01 \\
\text { Fold change }>2\end{array}$ & $50 \mathrm{miRNAs}$ & $\begin{array}{l}\text { An in silico } \\
\text { analysis identified } \\
49 \text { molecular } \\
\text { networks }\end{array}$ & 61 \\
\hline
\end{tabular}

Note: PE: Peritoneal endometriosis; OE: Ovarian endometriosis

mechanisms for tightly controlling proliferative signals (68). Furthermore, a study suggested that autoregulation between E2F1-3 and miR-20a is important for preventing abnormal accumulation of E2F1-3 and may play a role in the regulation of cellular proliferation and apoptosis (69). These findings suggested that down-regulation of miR-20a in endometriosis might promote the proliferative function of cyclin D1. However, in one study (64), miR-20a was shown to be upregulated in endometriotic tissue compared to eutopic endometrium by qRT-PCR; in contrast, in the two studies that demonstrated down-regulation of miR-20a, qRT-PCR validation studies were not performed. In addition, the function of individual miRNAs may be cell-type specific. The miR$17 / 20$ cluster has been found to function either as onco-
miRNA or as a tumor suppressor depending on the cell type (69). The role of miRNAs in endometriosis pathophysiology is only beginning to be unraveled. Given that post-transcriptional regulation is important in endometriosis (61), it is highly likely that more extensive analyses will follow. The integrative analysis of target prediction, miRNA, and gene expression profiles could reveal biologically relevant regulatory circuits in endometriosis pathophysiology.

\section{ARRAY COMPARATIVE HYBRIDIZATION (ARRAY CGH)}

GENOMIC

Array CGH is a method used to detect segmental DNA copy number alterations. Advances in this technology 
have enabled high-resolution identification of genetic alterations and copy number variations on a genome-wide scale. Using LCM and high-resolution CGH microarrays, $\mathrm{Wu}$ et al. demonstrated that epithelial cells of the eutopic and ectopic endometrium of 5 women with endometriosis (3 peritoneal, 2 ovarian) share a sizable portion of genomic alterations (70) (Table 3). DNA copy gain and loss appeared in all 5 cases. The Human Bacterial Artificial Chromosomes (BAC) arrays contain 2,632 BAC clones, spanning the entire human genome with $\sim 1.0-\mathrm{Mb}$ resolution were used for this study (70). In contrast, an array-CGH analysis of endometriotic lesions without LCM from a total of 10 ovarian endometriosis samples demonstrated no genomic aberrations (20) (Table 3). These investigators used Arrays, which contains 5,659 clones spotted in triplicate, which provides an $\sim 1.0-\mathrm{Mb}$ resolution across the human genome (71). A study of papillary thyroid carcinoma demonstrated a higher prevalence of aberrations detected using a combination of LCM and array-based $\mathrm{CGH}$ than previously described in the literature (72). The lack of LCM might partly explain the absence of aberrations detected in the latter study. A previous study of allelic imbalance in endometriosis reported loss of heterozygosity in $28 \%$ of cases of microdissected endometriosis, on chromosome arms $9 p(18 \%, 6 / 34)$, $11 \mathrm{q}(18 \%, 6 / 33)$, and 22q $(15 \%, 6 / 40)(73)$. In addition, a study in which microsatellite DNA assays were performed for 17 markers in ovarian endometriosis using whole tissues demonstrated that the incidence of allelic imbalance was $36.4 \%$ (74). Of these, the 9p21 locus showed loss of heterozygosity in $27.3 \%(6 / 22)$ of ovarian endometriosis samples (74).

\section{CHROMATIN IMMUNOPRECIPITATION (CHIP) WITH HYBRIDIZATION OF MICROARRAYS (CHIP-ON-CHIP)}

Epigenetic modifications, including DNA and histone methylation, play a pivotal role in gene regulation. Several studies have provided evidence that endometriosis is an epigenetic disease. Details about epigenetics in endometriosis are reviewed elsewhere (75) The first results of genome-wide $\mathrm{CpG}$ methylation profiling of endometriosis were recently reported (76), and more extensive studies will likely follow. Given the direct association between epigenetics and gene expression, much is to be expected from this research. Borghese et al. identified a total of 35 genes that had both methylation and expression alterations in endometriosis using Affymetrix GeneChip Human Promoter 1.0R Arrays (76). Among these 35 genes, only scavenger receptor class B1 (SCARB1) genes have been previously reported to be involved in endometriosis pathogenesis. Higher expression levels of SCARB1 genes in endometriosis compared to endometrium might play a role in the uptake of highdensity lipoprotein (HDL) cholesterol, supporting in situ estrogen production (77). Endometriosis is an estrogendependent disease, and in situ estrogen production may play a central role in its pathogenesis (1). Up-regulation of aromatase in endometriosis occurs due to aberrant DNA demethylation in a nonpromoter $\mathrm{CpG}$ island (78). These genes may therefore represent potential targets for epigenetic-based therapies designed to restore normal gene expression patterns in endometriosis. In addition, as the study investigators mentioned, further in-depth studies of the remaining 34 genes could be of great interest (76). In addition, the study authors detected the localization of hypermethylated regions at the ends of the chromosomes, whereas hypomethylation appeared to be a random event (76). Because many cancer cells display global hypomethylation of their genome, which has been causally linked to increased chromosomal instability and tumor progression, the authors hypothesized that the asymmetry in hypermethylation/hypomethylation could be regarded as an additional mechanism "invented" by the endometriotic cells to preserve themselves from the risk of malignant transformation (76). These findings suggested that cell proliferation associated with ovarian endometriosis might be tightly regulated, supporting the findings by Banz et al (21) (Table 1).

One study performed a simultaneous highresolution, whole-genome analysis of human breast cell lines to correlate data from gene expression, epigenetic (DNA methylation), and combination copy number variant/single nucleotide polymorphism microarrays using Affymetrix gene expression (U133), promoter (1.0R), and $\mathrm{SNP} / \mathrm{CNV}$ (SNP 6.0) microarray platforms (79). The use of platforms that share the common Affymetrix technology base permitted a robustness of design and economy that allowed standardized bioinformatic assessment and crossreferencing of the data sets, using a single software bioinformatics package (Partek Genomic Suite) to import, analyze, and cross-reference raw data from the various microarray platforms (79). The study authors identified specific gene subsets with specific relationships between expression, methylation status, and copy number (79). Among the genes with decreased expression, $16.5 \%$ $(405 / 2446)$ were hypermethylated. Among genes with increased expression, $10.3 \% \quad(246 / 2400)$ were hypomethylated (79). These findings suggested that epigenetic (i.e., DNA methylation) deregulation might be responsible for gene expression in fewer than $20 \%$ of genes in this study model. Thus, the authors demonstrated the utility of microarray technologies in identification of potential targets for epigenetic-based therapies in the context of multiple genomic characteristics (gene copy number, DNA methylation, and expression) to restore normal gene expression patterns (79). The methodology demonstrated in the study could also be applied to endometriosis.

In vitro studies have demonstrated that histone deacetylase inhibitors (HDACIs), such as trichostatin A (TSA), can suppress proliferation and cell cycle progression in endometrial stromal cells $(80,81)$, inhibit IL-1 $\beta$-induced COX-2 expression (82) up-regulate PPAR (83), attenuate invasion, and reactivate silenced E-cadherin gene expression (84). In addition, and perhaps more importantly, TSA treatment resulted in a significantly reduced average lesion size compared to those in untreated mice, as well as a significant improvement in response to a noxious thermal stimulus in a mouse endometriosis model (85). 
Epigenetic alterations may also contribute to miRNA deregulation. One study suggested that DNA demethylation and histone deacetylase inhibition can activate expression of miRNAs that may act as tumor suppressors in human cancer cells (86). Given that both epigenetic and miRNA alterations might be very important in endometriosis pathophysiology, it would be interesting to investigate whether ncRNAs, including miRNA, are epigenetically regulated in this disease.

\section{SINGLE NUCLEOTIDE POLYMORPHISMS (SNPS) ARRAY}

A recent publication reported a genome-wide association study (GWAS) using 1,423 cases and 1,318 controls in the Japanese population using the Illumina HumanHap 550k BeadChip assay to identify genetic loci associated with endometriosis (87). To further validate the results of the first-stage analysis, the study authors performed a replication study using an independent set of 484 cases and 3,974 controls (87). The authors identified a significant association between endometriosis and rs10965235 ( $\mathrm{P}=5.57 \times 10^{-12}$, odds ratio=1.44), which is located in CDKN2BAS on chromosome 9p21, encoding the cyclin-dependent kinase inhibitor 2B antisense RNA (87). CDKN2BAS regulates the expression of CDKN2B, CDKN2A, and ARF (87). CDKN2A is one of the cellcycle-dependent kinase inhibitors that acts as a negative cell cycle regulator. This is the first GWAS to identify genetic variants associated with endometriosis. A previous microsatellite DNA assay of a total of 17 markers in ovarian endometriosis demonstrated an allelic imbalance incidence of $36.4 \%$. Of these, the $9 \mathrm{p} 21$ locus showed loss of heterozygosity in $27.3 \%(6 / 22)$ of ovarian endometriosis samples (74). A recent study within diverse populations of European origin identified three loci associated with melanoma risk, one of which is the 9p21 locus (88). Several studies have reported an association between endometriosis and cutaneous melanoma $(89,90)$. In addition, a French national cohort study of 97,215 women demonstrated for the first time a positive dose effect on the relationship between the risk of endometriosis and skin sensitivity to sun exposure, as measured by the number of naevi and freckles (91). It has been reported that naevi count is associated with the CDK2A region (9p21) (92). These findings strongly suggested that alterations in the CDK2A region $(9 \mathrm{p} 21)$ represent a commonality between endometriosis and melanoma. In addition, GWAS studies demonstrated that the CDK2A region is associated with coronary disease (93) and type 2 diabetes (94). These findings suggested the possibility of common etiologic pathways for these diverse conditions. However, an association between the CDK2A region and endometriosis has also been demonstrated in the Japanese population, which has a much lower risk for malignant melanoma. Further studies of population samples with diverse geographic ancestries are required to validate these findings. This first GWAS study on endometriosis demonstrated a very small odds ratio (effect size), as is observed for other complex diseases. The genetic loci associated with disease generally explain very little about the disease risk $(95,96)$. The odds of having a risk genotype at a particular disease locus, given that one has the disease, divided by the odds of having a risk genotype given that one does not have the disease, are typically less than $1.5(95,96)$. Given the small effect sizes, it is less likely that genetic tests will be used to directly assess individual risk of disease (96); nonetheless, knowledge of disease pathways may contribute to the development of improved diagnostic methods (97). However, much remains to be learned about how variations in DNA influence gene expression, protein coding, and disease phenotypes (95). Further studies are required to elucidate the functional roles that these implicated genes play in endometriosis.

\section{SUMMARY AND PERSPECTIVE}

Since 2002, and particularly in the past few years, the utility of various DNA microarray technologies in endometriosis has rapidly and tremendously evolved; DNA microarray studies provide extremely important information that enable a better understanding of pathophysiology and disease etiology. DNA microarray technologies are powerful tools in the laboratory setting for scientific research, hypothesis generation, and the production of leads for subsequent validation through more sophisticated technologies. However, much additional analysis is required before the identification of endometriosis markers that can be used for noninvasive diagnosis, development of prevention strategies and more effective targeted therapies, and prediction of recurrence.

While the value of biomarkers - characteristics that are evaluated as indicators of normal or pathogenic biological processes, or responses to an intervention - is widely appreciated, the number of qualified biomarkers is small. The results of the first set of studies by the Predictive Safety Testing Consortium (PSTC) — which involves multiple drug companies, non-profit organizations, the Food and Drug Administration (FDA), and the European Medicines Agency (EMA) - have recently been reported (96). With the aim of enhancing understanding of the regulatory significance of such biomarker data by regulators and sponsors, the FDA initiated a program in 2004 to allow sponsors to submit exploratory genomic data voluntarily, without immediate regulatory impact. Approximately two-thirds (35 total) of the voluntary genomic data submissions (VXDSs) have focused on clinical applications of exploratory biomarkers. Clinical submissions have been broadly focused, and include oncology therapies as well as disease and drug response markers associated with Alzheimer's disease, hypertension, depression, obesity, and rheumatoid arthritis. The primary technology platforms for VXDS have been differential gene expression from microarrays and genotype-phenotype relationships. Such collaborations should ultimately play a key role in the qualification of the next generation of biomarkers in endometriosis.

Common human diseases originate from a complex interplay between constellations of changes in DNA and a broad range of factors such as diet, age, gender, and exposure to environmental toxins (96); endometriosis is no exception (1). Schadt et al. recently noted that the 
molecular biology revolution led to an intense focus on the study of interactions between DNA, RNA, and protein biosynthesis to develop a more comprehensive understanding of the cell (97). One consequence of this focus was a reduced attention to whole-system physiology, making it difficult to link molecular biology to clinical medicine. A transition from the molecular level to the system promises to revolutionize our understanding of complex biological processes such as disease. Schadt et al. summarized the progress made over the past few years to integrate DNA variation, molecular profiling, and clinical data collected in populations to construct causal probabilistic networks of disease, providing a more comprehensive view of disease than can be achieved by examining the individual data (97). Integrating large-scale, high-dimensional molecular and physiological data holds promise not only for defining the molecular networks that directly respond to genetic and environmental perturbations associated with disease but also for causally associating such networks with the physiological states associated with disease dimensions on their own (97). Integrating a genomics approach with reconstructing networks not only leads to more predictive network models, but also may save time and money by decreasing the amount of data (i.e., number of experiments and number of subjects) (98). One study provided preliminary evidence that integrating genomic information with clinical and pathological risk factors can refine prognosis and improve therapeutic strategies for early-stage breast cancer. A total of 964 breast tumor samples were clinically annotated from five data sets (Gene Expression Omnibus [GEO] microarray data repository at http://www.ncbi.nlm.nih.gov/geo/) (99). All patients in each data set were followed up for an average of $>11$ years (99).

Integrating large-scale, high-dimensional molecular and physiological data in collaboration with both scientific and clinical communities may enable identification of clinically relevant endometriosis markers for patients with endometriosis. Recent advances of deep sequencing technology might boost collabotarive, comparative and integrative genomics studies in endometriosis $(100,101)$.

\section{ACKNOWLEDGEMENTS}

This study was supported in part by grants PHRC 2005-2007 of CHU Clermont-Ferrand, la Fondation de l'Avenir (ET 5-403, ET6-427, ET8-501 and ET9-523, Paris, France), le Conseil Régional d'Auvergne (Recherche et Innovation Technologique) (Clermont-Ferrand, France) and Karl Storz Endoscopy \& GmbH (Tuttlingen, Germany).

\section{REFERENCES}

1. Giudice L.C., L. Kao: Endometriosis. Lancet 364, 17891799 (2004)

2. Kao L.C., A. Germeyer, S. Tulac, S. Lobo, J.P. Yang, R.N. Taylor, K. Osteen, B.A. Lessey, L.C. Giudice: Expression profiling of endometrium from women with endometriosis reveals candidate genes for disease-based implantation failure and infertility. Endocrinology 144, 2870-2881 (2003)

3. Guo S.W., Y. Wu, E. Strawn, Z. Basir, Y. Wang, G. Halverson, K. Montgomery, A. Kajdacsy-Balla: Genomic alterations in the endometrium may be a proximate cause for endometriosis. Eur J Obstet Gynecol Reprod Biol 116, 89-99 (2004)

4. Matsuzaki S., M. Canis M, C. Vaurs-Barrière C, O. Boespflug-Tanguy, B. Dastugue, G. Mage: DNA microarray analysis of gene expression in eutopic endometrium from patients with deep endometriosis using laser capture microdissection. Fertil Steril Suppl 2, 1180$1190(2005)$

5. Burney R.O., S. Talbi, A.E. Hamilton, K.C. Vo, M. Nyegaard, C.R. Nezhat, B.A. Lessey, L.C. Giudice: Gene expression analysis of endometrium reveals progesterone resistance and candidate susceptibility genes in women with endometriosis. Endocrinology 148, 3814-3826 (2007)

6. Sherwin J. R., A.M. Sharkey, A. Mihalyi, P. Simsa, R.D. Catalano, T.M. D'Hooghe: Global gene analysis of late secretory phase, eutopic endometrium does not provide the basis for a minimally invasive test of endometriosis. Hum Reprod 23, 1063-1068 (2008)

7. Burney R. O., A. E. Hamilton, L. Aghajanova, K. C. Vo, C. N. Nezhat, B. A. Lessey, L. C. Giudice: MicroRNA expression profiling of eutopic secretory endometrium in women with versus without endometriosis. Mol Hum Reprod 15, 625-631 (2009)

8. Eyster K. M., A. L. Boles, J. D. Brannian, K. A. Hansen: DNA microarray analysis of gene expression markers of endometriosis. Fertil Steril 77, 38-42 (2002)

9. Lebovic D. I., R. A. Baldocchi, M.D. Mueller, R. N. Taylor: Altered expression of a cell-cycle suppressor gene, Tob-1, in endometriotic cells by cDNA array analyses. Fertil Steril 78, 849-54 (2002)

10. Arimoto T., T. Katagiri, K. Oda, T. Tsunoda, T. Yasugi, Y. Osuga, H. Yoshikawa, O; Nishii, T. Yano, Y. Taketani, Y. Nakamura: Genome-wide cDNA microarray analysis of gene-expression profiles involved in ovarian endometriosis. Int J Oncol 22, 551-560 (2003)

11. Matsuzaki S., M. Canis, C. Vaurs-Barrière, J.L. Pouly, O. Boespflug-Tanguy, F. Penault-Llorca, P. Dechelotte, B. Dastugue, K. Okamura, G. Mage: DNA microarray analysis of gene expression profiles in deep endometriosis using laser capture microdissection. Mol Hum Reprod 10, 719-728 (2004)

12. Wu Y., A. Kajdacsy-Balla, E. Strawn, Z. Basir, G. Halverson, P. Jailwala, Y. Wang, X. Wang, S. Ghosh, G.W. Guo: Transcriptional characterizations of differences between eutopic and ectopic endometrium. Endocrinology 147, 232-246 (2006) 
13. Flores I., E. Rivera, S. Mousses, Y. Chen, E. Rozenblum: Identification of molecular markers for endometriosis in blood lymphocytes by using deoxyribonucleic acid microarrays. Fertil Steril 85, 1676-1683 (2006)

14. Van Langendonckt A., C. Punyadeera, R. Kamps, G. Dunselman, L. Klein-Hitpass, L.J. Schurgers, J. Squifflet, J. Donnez, P. Groothuis: Identification of novel antigens in blood vessels in rectovaginal endometriosis. Mol Hum Reprod 13, 875-886 (2007).

15. Eyster K.M., O. Klinkova, V. Kennedy, K. A. Hansen: Whole genome deoxyribonucleic acid microarray analysis of gene expression in ectopic versus eutopic endometrium. Fertil Steril 88, 1505-1533 (2007)

16. Mettler L., A. Salmassi, T. Schollmeyer, A.G. Schmutzler, F. Püngel, W. Jonat: Comparison of c-DNA microarray analysis of gene expression between eutopic endometrium and ectopic endometrium (endometriosis). $J$ Assist Reprod Genet 24, 249-258 (2007)

17. Hever A., R.B. Roth, P. Hevezi, M.E. Marin, J.A. Acosta, H. Acosta, J. Rojas, R. Herrera, D. Grigoriadis, E. White, P.J. Conlon, R. A. Maki, A. Zlotnik: Human endometriosis is associated with plasma cells and overexpression of B lymphocyte stimulator. Proc Natl Acad Sci U S A 104, 1245112456 (2007)

18. Hull M. L., C. R. Escareno, J. M. Godsland, J. R. Doig, C. M. Johnson, S. C. Phillips, S. K; Smith, S. Tavaré, C. G. Print, D. S. Charnock-Jones: Endometrial-peritoneal interactions during endometriotic lesion establishment. Am J Pathol 173, 700-715 (2008)

19. Borghese B., F. Mondon, J. C. Noël, I. Fayt, T. M. Mignot, D. Vaiman, C. Chapron: Gene expression profile for ectopic versus eutopic endometrium provides new insights into endometriosis oncogenic potential. Mol Endocrinol 22, 2557 $2562(2008)$

20. Zafrakas M., B.C. Tarlatzis, T. Streichert, F. Pournaropoulos, U. Wölfle, S. J. Smeets, B. Wittek, G. Grimbizis, R.H. Brakenhoff, K. Pantel, J. Bontis, C. Günes: Genome-wide microarray gene expression, array-CGH analysis, and telomerase activity in advanced ovarian endometriosis: a high degree of differentiation rather than malignant potential. Int J Mol Med 21, 335-344 (2008)

21. Banz C., U. Ungethuem, R. J. Kuban, K. Diedrich, E. Lengyel, D. Hornung: The molecular signature of endometriosis-associated endometrioid ovarian cancer differs significantly from endometriosis-independent endometrioid ovarian cancer. Fertil Steril 94, 1212-1217 (2010)

22. Gress T. M., J. D. Hoheisel, G. G. Lennon, G. Zehetner, H. Lehrach: Hybridization fingerprinting of high-density cDNAlibrary arrays with cDNA pools derived from whole tissues. Mamm Genome 3, 609-619 (1992)

23. Schena M., D. Shalon, R. W. Davis, P. O. Brown: Quantitative monitoring of gene expression patterns with a complementary DNA microarray. Science 270, 467-470 (1995)

24. Fodor S. P., J. L. Read, M. C. Pirrung, L. Stryer, A. T. Lu, D. Solas: Light-directed, spatially addressable parallel chemical synthesis. Science 251, 767-773 (1991)

25. Lockhart D. J., H. Dong, M. C. Byrne, M.T. Follettie, M. V. Gallo, M. S. Chee, M. Mittmann, C. Wang, M. Kobayashi, H. Horton, E. L. Brown: Expression monitoring by hybridization to high-density oligonucleotide arrays. Nat Biotechnol 14, 1675-1680 (1996)

26. Chee M., R. Yang, E. Hubbell, A. Berno, X. C. Huang, D., Stern, J. Winkler, D. J. Lockhart, M. S. Morris, S. P. Fodor: Accessing genetic information with high-density DNA arrays. Science 274, 610-614 (1996)

27. Wodicka L., H. Dong, M. Mittmann, M.H. Ho, D. Lockhart: Genome-wide expression monitoring in Saccharomyces cerevisiae. Nat Biotechnol 15, 1359-1367 (1997)

28. Moore P.A., O. Belvedere, A. Orr, K. Pieri, D. W. LaFleur, P. Feng, D. Soppet, M. Charters, R. Gentz, D. Parmelee, Y. Li, O. Galperina, J. Giri,V. Roschke, B. Nardelli, J. Carrell, S. Sosnovtseva, W. Greenfield, S.M. Ruben, H. S. Olsen, J. Fikes, D. M. Hilbert: BLyS: member of the tumor necrosis factor family and B lymphocyte stimulator. Science 285, 260-263 (1999)

29. Mackay F., S. A. Woodcock, P. Lawton, C. Ambrose, M. Baetscher, P. Schneider, J. Tschopp, J. L. Browning: Mice transgenic for BAFF develop lymphocytic disorders along with autoimmune manifestations. J Exp Med 190, 1697-1710 (1999)

30. Khare S.D., I. Sarosi, X.Z. Xia, S. McCabe, K. Miner, I. Solovyev, N. Hawkins, M. Kelley, D. Chang, G. Van, L. Ross, J. Delaney, L ; Wang, D. Lacey, W. J. Boyle, H. Hsu:

Severe B cell hyperplasia and autoimmune disease in TALL-1 transgenic mice. Proc Natl Acad Sci USA 97, 3370-3375 (2000)

31. Gross J.A., J. Johnston, S. Mudri, R. Enselman, S. R. Dillon, K. Madden, W. Xu, J. Parrish-Novak, D. Foster, C. Lofton-Day, M. Moore, A. Littau, A. Grossman, H. Haugen, K. Foley, H. Blumberg, K. Harrison, W. Kindsvogel, C. H. Clegg: TACI and BCMA are receptors for a TNF homologue implicated in B-cell autoimmune disease. Nature, 404:995-999 (2000)

32. Cheema G.S., V. Roschke, D. M. Hilbert, W. Stohl: Elevated serum B lymphocyte stimulator levels in patients with systemic immune-based rheumatic diseases. Arthritis Rheum 44, 1313-1319 (2001)

33. Zhang J., V. Roschke, K.P. Baker, Z. Wang, G. S. Alarcón, B. J. Fessler, H. Bastian, R. P. Kimberly, T. Zhou: Cutting edge: a role for B lymphocyte stimulator in systemic lupus erythematosus. J Immunol 166, 6-10 (2001) 
34. Petri M., W. Stohl, W. Chatham, W. J. McCune, M. Chevrier, J. Ryel, V. Recta, J. Zhong, W. Freimuth: Association of plasma B lymphocyte stimulator levels and disease activity in systemic lupus erythematosus. Arthritis Rheum 58, 2453-2459 (2008)

35.Sinaii N., S. D. Cleary, M. L. Ballweg, L. K. Nieman, P. Stratton: High rates of autoimmune and endocrine disorders, fibromyalgia, chronic fatigue syndrome and atopic diseases among women with endometriosis: a survey analysis. Hum Reprod 17, 2715-2724 (2002)

36. Sanz I., F. E. Lee: B cells as therapeutic targets in SLE. Nat Rev Rheumatol 6, 326-337 (2010)

37. Groothuis P.G., A. W. Nap, E. Winterhager, R. Grümmer: Vascular development in endometriosis. Angiogenesis 8, 147-156 (2005)

38. Buckanovich R. J., D. Sasaroli, A. O'brien-Jenkins, J. Botbyl, J. R. Conejo-Garcia, F. Benencia, L. A. Liotta, P. A. Gimotty, G. Coukos: Use of immuno-LCM to identify the in situ expression profile of cellular constituents of the tumor microenvironment. Cancer Biol Ther 5, 635-642 (2006)

39. St Croix B., C. Rago, V. Velculescu, G. Traverso, K. E. Romans, E. Montgomery, A. Lal, G. J. Riggins, C. Lengauer, B. Vogelstein, K. W. Kinzler: Genes expressed in human tumor endothelium. Science 289, 1197-1202 (2000)

40. Parker B.S., P. Argani, B. P. Cook, H. Liangfeng, S. D. Chartrand, M. Zhang, S. Saha, A. Bardelli, Y. Jiang, T.B. St Martin, M. Nacht, B. A. Teicher, K. W. Klinger, S. Sukumar, S. L. Madden: Alterations in vascular gene expression in invasive breast carcinoma. Cancer Res 64, 7857-7866 (2004)

41. Bhati R., C. Patterson, C. A. Livasy, C. Fan, D. Ketelsen, Z. Hu, E. Reynolds, C. Tanner, D. T. Moore, F. Gabrielli, C. M. Perou, N. Klauber-DeMore: Molecular characterization of human breast tumor vascular cells. $\mathrm{Am} \mathrm{J}$ Pathol 172, 1381-1390 (2008)

42. Kyama C.M., A. Mihalyi, P. Simsa, H. Falconer, V. Fulop, J.M. Mwenda, K. Peeraer, C. Tomassetti, C. Meuleman, T.M. D'Hooghe: Role of cytokines in the endometrial-peritoneal cross-talk and development of endometriosis. Front Biosci (Elite Ed) 1, 444-454 (2009)

43. Umezawa M., N. Tanaka, H. Tainaka, K. Takeda, T. Ihara, M. Sugamata: Microarray analysis provides insight into the early steps of pathophysiology of mouse endometriosis model induced by autotransplantation of endometrium. Life Sci 84, 832-837 (2009)

44. Flores I., E. Rivera, L. A. Ruiz, O. I. Santiago, M. W. Vernon, C. B. Appleyard: Molecular profiling of experimental endometriosis identified gene expression patterns in common with human disease. Fertil Steril 87, 1180-1199 (2007)
45. Pelch K.E., A. L. Schroder, P. A. Kimball, K. L. Sharpe-Timms, J. W. Davis, S. C. Nagel: Aberrant gene expression profile in a mouse model of endometriosis mirrors that observed in women. Fertil Steril 93, 1615$1627(2010)$

46. Vercellini P., F. Parazzini, G. Bolis, S. Carinelli, M. Dindelli, N. Vendola, L. Luchini, P.G. Crosignani: Endometriosis and ovarian cancer. Am J Obstet Gynecol $169,181-182(1993)$

47. McMeekin D.S., R.A. Burger, A. Manetta, P. DiSaia, M.L. Berman: Endometrioid adenocarcinoma of the ovary and its relationship to endometriosis. Gynecol Oncol 59, 81-86 (1995)

48. Sainz de La Cuesta R., J.H. Eichorn, L.W. Rice, A.F. Fuller, N. Nikurui, B.A. Goff : Histologic transformation of benign endometriosis to early epithelial ovarian cancer. Gynecol Oncol 60, 38-44 (1996)

49. Fukunaga M., K. Nomura, E. Ishikawa, S. Ushigome: Ovarian atypical endometriosis: its close association with malignant epithelial tumours. Histopathology 30, 249-55 (1997)

50. Marquez R.T., K.A. Baggerly, A.P. Patterson, J. Liu, R. Broaddus, M. Frumovitz, E.N. Atkinson, D.I. Smith, L. Hartmann, D. Fishman, A. Berchuck, R. Whitaker, D.M. Gershenson, G.B. Mills, R.C. Bast Jr, K.H. Lu: Patterns of gene expression in different histotypes of epithelial ovarian cancer correlate with those in normal fallopian tube, endometrium, and colon. Clin Cancer Res 11, 6116-6126 (2005)

51. Aboseif S., A. El-Sakka, P. Young, G. Chnha: Mesenchymal reprogramming of adult human epithelial differentiation. Differentiation 65, 113-118 (1999)

52. Liotta L.A., E.C. Kohn: The microenvironment of the tumour-host interface. Nature 411, 375-379 (2001)

53. Rogers P.A., T.M. D'Hooghe, A. Fazleabas, C. E. Gargett, L. C. Giudice, G.W. Montgomery, L. Rombauts, L.A. Salamonsen, K.T. Zondervan:. Priorities for endometriosis research: recommendations from an international consensus workshop. Reprod Sci 16, 335-346 (2009)

54. Somigliana E., P. Vercellini, P. Vigano, L. Benaglia, P. G. Crosignani, L. Fedele: Non-invasive diagnosis of endometriosis: the goal or own goal? Hum Reprod 25, $1863-1868$ (2000)

55. Taniguchi F., T. Harada, H. Miyakoda, T. Iwabe, I. Deura, Y. Tagashira, A. Miyamoto, A. Watanabe, K. Suou, T. Uegaki, N. Terakawa: TAK1 activation for cytokine synthesis and proliferation of endometriotic cells. Mol Cell Endocrinol 307, 196-204 (2009)

56. Watanabe A., F. Taniguchi, M. Izawa, K. Suou, T. Uegaki, E. Takai, N. Terakawa, T. Harada: The role of 
survivin in the resistance of endometriotic stromal cells to drug-induced apoptosis. Hum Reprod 24, 3172-3179 (2009)

57. Harada T., F. Taniguchi, M. Izawa, Y. Ohama, Y. Takenaka, Y. Tagashira, A. Ikeda, A. Watanabe, T. Iwabe, N. Terakawa: Apoptosis and endometriosis. Front Biosci 12, 3140-3151 (2007)

58. Izawa M., T. Harada, I. Deura, F.Taniguchi, T. Iwabe, N. Terakawa: Drug-induced apoptosis was markedly attenuated in endometriotic stromal cells. Hum Reprod 21, 600-604 (2006)

59. LaCasse E.C., S.Baird S, R.G. Korneluk, A.E. MacKenzie: The inhibitors of apoptosis (IAPs) and their emerging role in cancer. Oncogene 17, 3247-3259 (1998)

60. Zhang H., M. Li, X. Zheng, Y. Sun, Z. Wen, X. Zhao: Endometriotic stromal cells lose the ability to regulate cellsurvival signaling in endometrial epithelial cells in vitro. Mol Hum Reprod 15, 653-663 (2009)

61. Wren J.D., Y. Wu, S.W. Guo: A system-wide analysis of differentially expressed genes in ectopic and eutopic endometrium. Hum Reprod 22, 2093-2102 (2007)

62. Bartel, D.P.: MicroRNAs: genomics, biogenesis, mechanism, and function. Cell 116, 281-297 (2004)

63. Bartel, D.P.: MicroRNAs: target recognition and regulatory functions. Cell 136, 215-233 (2007)

64. Pan Q., X. Luo, T. Toloubeydokhti, N. Chegini: The expression profile of micro-RNA in endometrium and endometriosis and the influence of ovarian steroids on their expression. Mol Hum Reprod 13, 797-806 (2007)

65. Ohlsson Teague E.M., K.H. Van der Hoek, M.B. Van der Hoek, N. Perry, P. Wagaarachchi, S.A. Robertson, C.G. Print, L.M. Hull: MicroRNA-regulated pathways associated with endometriosis. Mol Endocrinol 23, 265-275 (2009)

66. Filigheddu N., I. Gregnanin, P.E. Porporato, D. Surico, B. Perego, L. Galli, C. Patrignani, A. Graziani, N. Surico: Differential expression of microRNAs between eutopic and ectopic endometrium in ovarian endometriosis. $J$ Biomed Biotechnol 2010, 369549 (20010)

67. Teague E.M., C. G. Print, M. L. Hull: The role of microRNAs in endometriosis and associated reproductive conditions. Hum Reprod Update 16, 142-165 (2010)

68. Yu Z ., C. Wang, M. Wang, Z. Li, M.C. Casimiro, M. Liu, K. Wu, J. Whittle, X. Ju, T. Hyslop, P. McCue, R. G. Pestell: A cyclin D1/microRNA 17/20 regulatory feedback loop in control of breast cancer cell proliferation. $J$ Cell Biol 182, 509-517 (2008)

69. Sylvestre Y., V. De Guire, E. Querido, U. K. Mukhopadhyay, V. Bourdeau, F. Major, G. Ferbeyre, P. Chartrand: An E2F/miR-20a autoregulatory feedback loop. J Biol Chem 282, 2135-2143 (2007)
70. Wu Y., E. Strawn, Z. Basir, Y. Wang, G. Halverson, P. Jailwala, S.W. Guo: Genomic alterations in ectopic and eutopic endometria of women with endometriosis. Gynecol Obstet Invest 62, 148-159 (2006)

71. Smeets S.J., B. J. Braakhuis, S. Abbas, P. J. Snijders, B. Ylstra, M.A.van de Wiel, G. A. Meijer, C. R. Leemans, R. H. Brakenhoff: Genome-wide DNA copy number alterations in head and neck squamous cell carcinomas with or without oncogene-expressing human papillomavirus. Oncogene 25, 2558-2564 (2006)

72. Finn S., P. Smyth, E. O'Regan, S. Cahill, M. Toner, C. Timon, R. Flavin, J. O'Leary, O. Sheils: Low-level genomic instability is a feature of papillary thyroid carcinoma: an array comparative genomic hybridization study of laser capture microdissected papillary thyroid carcinoma tumors and clonal cell lines. Arch Pathol Lab Med 131, 65-73 (2007)

73. Jiang X., A. Hitchcock, E. J. Bryan, R.H. Watson, P. Englefield, E.J. Thomas, I.G. Campbell: Microsatellite analysis of endometriosis reveals loss of heterozygosity at candidate ovarian tumor suppressor gene loci. Cancer Res 56, 3534-3539 (1996)

74. Goumenou A.G., D.A. Arvanitis, I.M. Matalliotakis, E.E. Koumantakis, D.A. Spandidos: Microsatellite DNA assays reveal an allelic imbalance in p16(Ink4), GALT, p53, and APOA2 loci in patients with endometriosis. Fertil Steril 75, 160-165 (2001)

75. Guo S.W.: Epigenetics of endometriosis. Mol Hum Reprod 15, 587-607 (2009)

76. Borghese B., S. Barbaux, F. Mondon, P. Santulli, G. Pierre, G. Vinci, C. Chapron, D. Vaiman: Genome-Wide Profiling of Methylated Promoters in Endometriosis Reveals a Subtelomeric Location of Hypermethylation. Mol Endocrinol (2010) in press

77. Ramachandran S., M. Song, A.A. Murphy, S. Parthasarathy: Expression of scavenger receptor class B1 in endometrium and endometriosis. J Clin Endocrinol Metab 86, 3924-3928 (2001)

78. Izawa M., F. Taniguchi, T. Uegaki, E; Takai, T. Iwabe, N. Terakawa, T. Harada: Demethylation of a nonpromoter cytosine-phosphate-guanine island in the aromatase gene may cause the aberrant up-regulation in endometriotic tissues. Fertil Steril (2010) in press

79. Andrews J., W. Kennette, J. Pilon, A. Hodgson, A.B. Tuck, A.F. Chambers, D.I. Rodenhiser: Multi-platform whole-genome microarray analyses refine the epigenetic signature of breast cancer metastasis with gene expression and copy number. PLoS One 5, e8665 (2010)

80. Wu Y., S.W. Guo: Inhibition of proliferation of endometrial stromal cells by trichostatin A, RU486, CDB2914, N-acetylcysteine, and ICI 182780. Gynecol Obstet Invest 62, 193-205 (2006) 
81. Wu Y., S.W. Guo: Histone deacetylase inhibitors trichostatin A and valproic acid induce cell cycle arrest and p21 expression in immortalized human endometrial stromal cells. Eur J Obstet Gynecol Reprod Biol 137, 198-203 (2008)

82. Wu Y., S.W. Guo: Suppression of IL-1beta-induced COX2 expression by trichostatin A (TSA) in human endometrial stromal cells. Eur J Obstet Gynecol Reprod Biol 135, 88-93 (2007)

83. Wu Y., S.W. Guo: Peroxisome proliferator-activated receptor-gamma and retinoid $\mathrm{X}$ receptor agonists synergistically suppress proliferation of immortalized endometrial stromal cells. Fertil Steril 91, 2142-2147 (2009)

84. Wu Y., A. Starzinski-Powitz, S.W. Guo: Trichostatin A, a histone deacetylase inhibitor, attenuates invasiveness and reactivates E-cadherin expression in immortalized endometriotic cells. Reprod Sci 14, 374-382 (2007)

85. Lu Y., J. Nie, X. Liu, Y. Zheng, S.W. Guo: Trichostatin A, a histone deacetylase inhibitor, reduces lesion growth and hyperalgesia in experimentally induced endometriosis in mice. Hum Reprod 25, 1014-1025 (2010)

86. Saito Y., G. Liang, G. Egger, J. M. Friedman, J. C. Chuang, G. A. Coetzee, P.A. Jones: Specific activation of microRNA-127 with downregulation of the proto-oncogene BCL6 by chromatin-modifying drugs in human cancer cells. Cancer Cell 9, 435-443 (2006)

87. Uno S., H. Zembutsu, A. Hirasawa, A. Takahashi, M. Kubo, T. Akahane, D. Aoki, N. Kamatani, K. Hirata, Y. Nakamura Y: A genome-wide association study identifies genetic variants in the CDKN2BAS locus associated with endometriosis in Japanese. Nat Genet 42, 707-710 (2010)

88. Bishop D.T., F. Demenais, M.M. Iles, M. Harland, J. C. Taylor, E. Corda, J. Randerson-Moor, J.F. Aitken, M.F. Avril, E. Azizi, B. Bakker, G. Bianchi-Scarrà, B. Bressac-de Paillerets, D. Calista, L.A. Cannon-Albright, T. Chin-AWoeng, T. Debniak, G. Galore-Haskel, P. Ghiorzo, J. Gut I, Hansson, M. Hocevar, V. Höiom, J.L Hopper, C. Ingvar, P.A. Kanetsky, R.F. Kefford, M.T. Landi, J. Lang, J. Lubiński, R. Mackie, J. Malvehy, G.J. Mann, N.G. Martin, G.W. Montgomery, F.A. van Nieuwpoort, S. Novakovic, H. Olsson, S. Puig, M. Weiss, W. van Workum, D. Zelenika, K.M. Brown, A.M. Goldstein, E.M. Gillanders, A. Boland, P. Galan, D.E. Elder, N.A. Gruis, N.K. Hayward, G.M. Lathrop, J.H. Barrett, J.A. Bishop: Genome-wide association study identifies three loci associated with melanoma risk. Nat Genet 41, 920-925 (2009)

89. Hornstein M.D., P.P. Thomas, A.J. Sober, G. Wyshak, N.L. Albright, R.E. Frisch: Association between endometriosis, dysplastic naevi and history of melanoma in women of reproductive age. Hum Reprod 12, 143-145 (1997)

90. Gemmill J.A., P. Stratton, S.D. Cleary, M.L. Ballweg, N. Sinaii: Cancers, infections, and endocrine diseases in women with endometriosis. Fertil Steril 94, 1627-1631 (2010)

91. Kvaskoff M., S. Mesrine, F. Clavel-Chapelon, M.C. Boutron-Ruault: Endometriosis risk in relation to naevi, freckles and skin sensitivity to sun exposure: the French E3N cohort. Int J Epidemiol 38, 1143-1153 (2009)

92. Zhu G., G.W. Montgomery, M.R. James, J.M. Trent, N.K. Hayward, N.G. Martin, D.L. Duffy: A genome-wide scan for naevus count: linkage to CDKN2A and to other chromosome regions. Eur J Hum Genet 15, 94-102 (2007)

93. Helgadottir A., G. Thorleifsson, A. Manolescu, S. Gretarsdottir, T. Blondal, A. Jonasdottir, Jonasdottir A, A. Sigurdsson, A. Baker, A. Palsson, G. Masson, D.F. Gudbjartsson, K.P. Magnusson, K. Andersen, A.I. Levey, V.M. Backman, S. Matthiasdottir, T. Jonsdottir, S. Palsson, H. Einarsdottir, S. Gunnarsdottir, A. Gylfason, V. Vaccarino, W.C. Hooper, M.P. Reilly, C.B. Granger, H. Austin, D.J. Rader, S.H. Shah, A.A. Quyyumi, J.R. Gulcher, G. Thorgeirsson, U. Thorsteinsdottir, A. Kong, K. Stefansson: A common variant on chromosome 9p21 affects the risk of myocardial infarction. Science 316,1491-1493 (2007)

94. Scott L.J., K.L. Mohlke, L.L. Bonnycastle, C.J. Willer, Y. Li, W.L. Duren, M.R. Erdos, H.M. Stringham, P.S. Chines, A.U. Jackson, L. Prokunina-Olsson, C.J. Ding, A.J. Swift, N. Narisu, T. Hu, R. Pruim, R. Xiao, X.Y. Li, K.N. Conneely, N.L. Riebow, A.G. Sprau, M. Tong, P. P. White, K.N. Hetrick, M.W. Barnhart, C.W. Bark, J.L. Goldstein, L. Watkins, F. Xiang, J. Saramies, T.A. Buchanan, R.M. Watanabe, T.T. Valle, L. Kinnunen, G.R. Abecasis, E.W. Pugh, K.F. Doheny, R.N. Bergman, J. Tuomilehto, F.S. Collins, M. Boehnke: A genome-wide association study of type 2 diabetes in Finns detects multiple susceptibility variants. Science 31, 1341-1345 (2007)

95. Hrady J., A. Singleto: Genomewide association studies and human disease. $N$ Engl J Med 360, 1759-1768 (2009)

96. Manolio T.A.: Genomewide association studies and assessment of the risk of disease. $N$ Engl $J$ Med 363, 166-76 (2010)

97. Montgomery G.W., D.R. Nyholt, Z.Z. Zhao, S.A. Treloar, J.N. Painter, S.A. Missmer, S.H. Kennedy, K.T. Zondervan: The search for genes contributing to endometriosis risk. Hum Reprod Update 14, 447-457 (2008)

96. Goodsaid F.M., S. Amur, J. Aubrecht, M.E. Burczynski, K. Carl, J. Catalano, R. Charlab, S. Close, C. Cornu-Artis, L. Essioux, A. J. Fornace Jr, L; Hinman, H. Hong, I. Hunt, D. Jacobson-Kram, A. Jawaid, D. Laurie, L. Lesko, H.H. Li, K. Lindpaintner, J. Mayne, P. Morrow, M. Papaluca-Amati, T.W. Robison, J. Roth, I. Schuppe-Koistinen, L. Shi, O. Spleiss, W. Tong, S.L. Truter, J. Vonderscher, A. Westelinck, L. Zhang, I. Zineh I:Voluntary exploratory data submissions to the US FDA and the EMA: experience and impact. Nat Rev Drug Discov 9, 435-445 (2010)

97. Schadt E.E.: Molecular networks as sensors and drivers of common human diseases. Nature 461, 218-223 (2009)

98. Zhu J., M.C. Wiener, C. Zhang, A. Fridman, E. Minch, P.Y. Lum, J.R. Sachs, E. E. Schadt: Increasing the power to detect causal associations by combining genotypic and 
expression data in segregating populations. PLoS Comput Biol 3, e69 (2007)

99. Acharya C.R., D.S. Hsu, C.K. Anders, A. Anguiano, K. H. Salter, K.S. Walters, R.C. Redman, S.A. Tuchman, C.A. Moylan, S. Mukherjee, W.T. Barry, H.K. Dressman, G.S. Ginsburg, K.P. Marcom, K.S. Garman, G.H. Lyman, J.R. Nevins, A. Potti: Gene Expression Signatures, Clinicopathological Features, and Individualized Therapy in Breast Cancer. JAMA 299, 1574-1587 (2008)

100. 't Hoen PA, Y. Ariyurek, H.H. Thygesen, E. Vreugdenhil, R.H. Vossen, R.X. de Menezes, J.M. Boer, G.J. van Ommen, J.T. den Dunnen. Deep sequencing-based expression analysis shows major advances in robustness, resolution and inter-lab portability over five microarray platforms. Nucleic Acids Res ;36, e141 (2008)

101. Ribeiro-dos-Santos Â, A.S. Khayat, A. Silva, D.O. Alencar, J. Lobato, L. Luz, D.G. Pinheiro, L. Varuzza, M. Assumpção, P. Assumpção, S. Santos, D.L. Zanette, W.A. Silva Jr, R. Burbano, S. Darnet. Ultra-deep sequencing reveals the microRNA expression pattern of the human stomach. PLoS One 5, e13205 (2010)

Abbreviations: BLyS: B lymphocyte stimulator; CGH: comparative genomic hybridization; ChIP: chromatin immunoprecipitation; CpG: cytosine-phosphate-guanine; ESTs: Expressed Sequence Tag; FDA: Food and Drug Administration; LCM: laser capture microdissection; MGP: matrix Gla protein; microRNA: miRNA; SLE: systemic lupus erythematosus, SNP: Single nucleotide polymorphism; RA: rheumatoid arthritis; SCARB1: scavenger receptor class B1; TSA : trichostatin A ; VXDS : voluntary genomic data submission

Key Words: DNA microarray, DNA Copy Number,Endometrioiss, Epigenetics, Gene Expression, Genome Wide Association Study, microRNA, Review

Send correspondence to: Sachiko Matsuzaki, Centre Hospitalier Universitaire de Clermont-Ferrand, Chirurgie Gynecologique, 1, Place Lucie Aubrac, 63003 ClermontFerrand Cedex 1, France, Tel: 33473750138, Fax: 33473152079, E-mail: sachikoma@aol.com 